\title{
Creative Works of Alfred Tennyson in Russian (Not Found, Not Published and Lost)
}

\section{Dmitry Nikolayevich Zhatkin}

\author{
Department of Translation and Methods of Translation, \\ Penza State Technological University, Penza, Russian Federation
}

\author{
Doi:10.5901/mjss.2015.v6n4s4p228
}

\begin{abstract}
In the last decades in Russia the interest of researchers to problems of Russian perception of Alfred Tennyson has been essentially increased. It was expressed in particular by issuing the article by A.N.Girivenko «Tennyson in Russia: The history of perception» (1993), which included the bibliography of Russian translations, the complimented bibliography prepared by L.I.Volodarskaya and printed as an appendix to the edition of a new translation of «ldylls of the King» executed by V.V.Lunin (2001); monograph by V.K.Chernin «Alfred Tennyson and Russia: From history of the international literary ties» (2009); anthologies "Alfred Tennyson in Russian translations of XIX - early XX century» (2014) carried out by D.N.Zhatkin and V.K.Chernin. It gives the complete overview of nowadays Russian translations and transpositions of Alfred Tennyson. At the same time it is necessary to confess that only the Russian translational reception of Alfred Tennyson's works done in the period previous to 1917 have been comprehended at a worthy scientific level, whereas the Russian translations of subsequent time and literary-critical problems of perception of texts of the English Poet Laureate in Russia, the tradition of his creativity in works of Russian writers have not been practically studied. "The Russian theme» which is traditionally considered as the reflection of poet's ideological and political views in his poems devoted to actual events of the international life (Russian suppression of the Polish revolt in 1830-1831, the Crimean war of 1853-1856, etc.) has been comprehended in a one-sided manner, whereas the meetings of Tennyson with Russian writers that are also of great interest, require ordering the facts of his acquaintance with their works. In this article there named the Russian translations of Tennyson that remain not found ("Enoch Arden» by I.A.Bunin, some translations by S.M.Gorodetsky, N.S.Tikhonov, etc.), not printed (translations by E.S.Kudasheva, I.G.Shumsky, etc.) or forgotten ("Dead Soldier» by English scientist-polyglot Donald MacAlister, the publication of translation of "Cradle Song» by L.N.Martynov ("The Wind of these coasts...»), carried out in Omsk in the middle of 1940th, etc.). As response in original works of Russian writers to the image of Lady Godiva from Tennyson's poem of the same name there can be traditionally mentioned the poem by O.E.Mandelstam «With the majestic world I was only childishly connected...» (1931). The image has drawn attention of not only O.E.Mandelstam but of I.Severyanin, D.D.Burlyuk, I.A.Aksenov, A.S.Grin, and G.M.Shergova as well, and this fact allows to say that Tennyson's tradition has not been studied in the Russian literature yet. There has also been examined the possible influence of «In Memoriam» by Tennyson on creative works of such Russian writers as N.M.Minsky, A.A.Akhmatova, V.A.Merkurieva.
\end{abstract}

Keywords: Alfred Tennyson, Russian-English literary and historical and cultural ties, poetic translation, comparative analyses, tradition, the intercultural communications, the literary criticism, an art detail.

\section{Introduction}

Alfred Tennyson belongs to a number of few English writers who has received lifetime glory in Russia. The first publications about him, which appeared in 1847 on pages of «The Finnish Bulletin» (Tennyson and modern direction, 1847) and «The Literary Newspaper» (Porgues, 1847), and then in 1851 in «Library for Reading» (Milsand, 1851), in 1853 in «Pantheon» (Tennyson, the modern English poet, 1853), testified that Tennyson was recognized as the leading English poet of the Victorian Age. In particular, in his «Library for Reading» Milsand marked both the maturity of Tennyson's skill which possessed «consciousness of taste» able to change colour «by forms which he represents», and the surprising dissimilarity of the poet with his contemporaries and authors of previous time: «With greater intricacy than the Greek poets, he possesses everything that their best places contain: he is homogeneous and sweet» (Milsand, 1851: 95). Early Russian articles about Tennyson traditionally put accent on the difficulties that translators can encounter in Tennyson's texts that are notable for «originality of the form and style» (Porgues, 1847: 442): "There is not any opportunity to transfer unusual tenderness of colours, any mysterious character, any fantastic grace of his poems and ballads. Sometimes it is just "the fly buzzes on the windowpane", but it gives so much charm to the whole picture, so much inexpressible value, that the translator should give way to despair» (Tennyson and modern direction,1847: 29).

The first Russian poetic translation of Tennyson was «Godiva» by M.L.Mikhailov issued in №9 of 
«Contemporaries» in 1859 (Tennyson, 1859). In the next decades such poets as A.N.Pleshcheev, D.D.Minaev, D.L.Mikhalovsky, D.E.Min, L.N.Trefolev, D.N.Sadovnikov, V.G.Druzhinin, L.I.Umanets, F.F.Tyutchev, A.N.Barykova, V.S.Likhachev, F.A.Chervinsky, I.K.Kondratev, M.N.Shelgunov, A.M.Fedorov, O.N.Chyumina, etc were trying to comprehend the works of the English Poet Laureate. Among the writers, who were at the sources of Russian Sliver Age, N.M.Minsky («Ulysses», 1893; «Memory of a Friend», 1897) and V.S.Solovjev («When, black and mute...», 1895) were the first to interpret Tennyson's poetry; however the greatest contribution to the Russian reception of the works by Poet Laureate was made by K.D.Balmont. The most part of his translations are well-known and they are still being published nowadays. In «a Collection of company "Knowledge", 1906» there was published the new translation of «Godiva» executed by I.A.Bunin, which drew public attention; other translations and the transpositions of those years created by V.V.Gofman, A.A.Miloradovich, K.I.Tchukovsky, Vas.Smirnov etc., were simply not noticed, or published much later after the date of their creation. This circumstance together with the absence of any new translations of Tennyson (just as of many other works by English poets of XIX century) enabled L.N.Lunts to write in 1922 in his review of a collection «The Court yard of miracles» by I.V.Odoevtseva the following: «Russian poets have absolutely forgotten about the surprising English poetry of XIX century. I do not speak about Southey and Keats but who knows Tennyson or Browning in Russia?» (Lunts, 2004: 402).

In Soviet time only three translations of Tennyson, executed by S.Y.Marshak in 1940th - «At the sea-side» (other name by the first verse - «Break, break, break...»), «The Miller's Daughter», «The Eagle» were repeatedly printing; as a whole the interest of translators to this author, whose thinking mismatched and even contradicted the principles of the Soviet ideology, was minimal in those years. New splash of interest to Tennyson and his creative works started in the late 1970th and was connected with the activity of such translators as G.M.Kruzhkov, V.V.Rogov, A.Y.Sergeev, M.E.Sokovnin, V.V.Levik, I.M.Dyakonov, D.V.Shchedrovitsky, Y.D.Levin, G.E.Ben, V.V.Lunin, E.A.Solovkova, E.D.Feldman, M.Y.Boroditskaya, etc.

\section{Literature Review}

The first attempt to order the materials, concerning Alfred Tennyson's reception, was the bibliography «Foreign writers in the Russian literature: Tennyson» published in №11 of the magazine «Bibliographic a note», 1892, signed as «Provincial bibliographer». It was composed by N.N.Bakhtin (the Provincial bibliographer, 1892). In 1895 the publisher D.V. Baikov made an afford to prepare the bibliographic note for the edition of a poem by A.Tennyson «Mood» translated by A.M.Fedorov («Magdalena (Mood)») which included the information about eighteen translations of Tennyson's works into Russian (D.B., 1895).

The new stage of studying the Russian reception of Tennyson began only in 1990th when the article «Alfred Tennyson in Russia: history of perception» by A.N.Girivenko was published in 1993. It contained both the brief review of literary-critical judgments about Alfred Tennyson in the Russian literary criticism of XIX century, and the 68 records of the bibliography of Russian pre-revolutionary translations and texts «on motif» of Tennyson, which were not designated as translations (Girivenko, 1993). A.N.Girivenko together with A.R.Nedachina made a bibliographic index «English literature in the Russian criticism» (1994-1995), in the second part of the second book of which devoted to XIX century, there was the special section containing 62 records with the information about literary-critical perception of Tennyson's works in Russia (Girivenko and Nedachina 1995: 104-109). The edition of the translation of «ldylls of the King» executed by V.V.Lunin (2001) included the bibliography of Russian translations of Tennyson made by L.I.Volodarskaya with 62 records, 56 of which were related to the pre-revolutionary period, and 6 - to the Soviet (Volodarskaya 2001: 450-453).

The study of Russian translational reception of A. Tennyson's creativity in the early XXI century is connected with the names of V.K.Chernin and D.N.Zhatkin, in particular, in the co-authorship they published of a lot of articles in the leading Russian reviewed magazines (for example: Chernin and Zhatkin, 2009a; Chernin and Zhatkin, 2009b; Chernin and Zhatkin, 2009c; Chernin and Zhatkin, 2010a; Chernin and Zhatkin, 2010b; Chernin and Zhatkin, 2011; Chernin and Zhatkin, 2012). In 2009 V.K.Chernin published the monograph «Alfred Tennyson and Russia: From the history of the international literary ties» (Chernin, 2009). In 2014 there was issued the anthology «Alfred Tennyson in Russian translations of XIX - early XX century» created by D.N.Zhatkin and V.K.Chernin, that gave the complete overview of Russian translations and transpositions of the English author of the specified period. The book includes the bibliographic inquiry «Publications of Russian translations and transpositions of Tennyson's works», comprising 82 records (Zhatkin and Chernin, 2014: 700-707). After the issue the process of revealing of translations texts not entered into the book is going on; for example, there have been found and included into the book the translation of a poem «Stream» («I Am beating out quietly ...»), which was carried out in the 1900th by a subsequently known scientist-geologist and paleontologist A.N.Ryabinin and it was included into his book of original and translation poetry «After a thunder-storm», 
published in 1918 (Ryabinin, 1918 : 80-83).

In foreign literary criticism on the background of significant number of the works, devoted to studying the person and creativity of Tennyson (for example, Buckley, 1960; Buckley, 1966; Buckley, 1969; Hair, 1981; Henderson, 1978; Ricks, 1972; Thomson, 1986; Turner, 1976), the connection between his creative works and Russia remains less investigated. The unique monograph of a New Zealand scientist P.Waddington «Tennyson and Russia» is devoted to a problem of reconstruction of an image of Russia by Tennyson that was formed under influence of the international political events (suppression by Russian tsar Nikolai I of Polish revolt, the Crimean war 1853-1856, etc.) in a sharply negative aspect (Waddington, 1987); as a development of these ideas V.K.Chernin and D.N.Zhatkin published an article «"Russian theme" in literary creativity of Alfred Tennyson in a context of Russian-English public and literary ties of XIX century» in 2010 (Chernin and Zhatkin, 2010c). But there is some other not studied but very important aspect of the given theme - Russian meetings of Tennyson, the facts testifying his acquaintance with Russian writers and their works. Great efforts are needed for the researchers to generalize and order the specified materials and to process the significant number of sources in English, Russian and other languages.

\section{Materials and Methods}

Considering the works of the scientists-predecessors devoted to Russian reception of Alfred Tennyson we have found some lacunas of scientific knowledge, requiring filling with a new research material. Thus, we have concentrated our basic attention on unpublished and forgotten translations; on the evidences with the information about lost and not found translations; possibilities to find some new foreshortenings of studying well-known translations so as to introduce some unknown archival materials into a scientific turnover making the circumstances of their creation, publication, etc more precise.

The methodological base of research is based on fundamental works by M.P.Alekseev (Alekseev, 1983; Alekseev, 1991), Y.D.Levin (Levin, 1985), A.V.Fedorov (Fedorov, 1983), on the researches of history of poetic translation (G.R.Gachechiladze (Gachechiladze, 1972), E.G.Etkind (Etkind, 1963), P.M.Toper (Toper, 2001), A.N.Girivenko (Girivenko, 1993), etc.), on problems of Russian-English literary and historical and cultural interaction (A.A.Elistratova (Elistratova, 1960), L.M.Pavshok (Pavshok, 2008), N.P.Mikhalskaya (Mikhalskaya, 1995), B.G.Reizov (Reizov, 1966), N.I.Sokolova (the Sokolova, 1999), etc.). The works of researchers of creativity of A.Tennyson by (Buckley, 1960; Buckley, 1966; Buckley, 1969; Hair, 1981; Henderson, 1978; Ricks, 1972; Thomson, 1986; Turner, 1976) and his connections with Russia (Waddington, 1987) were of great help for us.

\section{Results}

The still unfound translations can be waiting for the future researches of Russian reception of Tennyson, the information of which is kept in various sources. Thus I.A.Bunin wrote to M.Gorky on August, 26th, 1909 about his translation of «Enoch Arden», the location of which is not known: «<...> soon I will finish Tennyson's "Enoch" - a fair ancient story about fishermen once rendered by Barykova. Do you remember "The Rescued"?» (Bunin, 2007: 123-124). The letter written by A.A.Block to Z.I.Grzhebin dated November, 2nd, 1907 refers to approximately the same period of time. It mentions in particular that «Gorodetsky has some good translations of Tennyson» (Alexander Block in «Pantheon», 2004: 323), but these translations have never been published. In his article «Russian meetings of William Morris», found in his archive and published in 1996, the academician M.P.Alekseev mentions that N.M.Minsky «has translated much of Tennyson, Shelley and Byron» (Alekseev, 1996 : 19), however there are only two of his translations of Tennyson published by now - «Ulysses» (Tennyson, 1893) and «Memories of a Friend» (Tennyson, 1897). It is possible that in this case archival search can have results. In 1923 one of the «Serapion brothers» N.S.Tikhonov, who later became the notable Soviet poet and the functionary of the Union of Writers of the USSR, unexpectedly translated A.Tennyson; it is possible to learn about it from his letter sent to L.N.Lunts not later than on October, 19th 1923: «l am cramming English and have been already translating Tennyson <...>» (Lunts, 2007: 493).

There are some found but not published translations of Tennyson in the Russian archives. So now we (together with V.K.Chernin) prepare for the publication the translation of «ldylls of the King» executed by the princess E.S.Kudasheva in early XX century kept in the Russian State Archive of the literature and art (f. 1346, list 1, unit of storage 201). She is known for her perusals of «Cain» by G.G.Byron, «Lost paradise » by G.Milton, works by E. SetonThompson, R.Kipling, Jerome K. Jerome, etc. In the Hand-written department of the Pushkin House there is a fund of I.G.Shumsky - the lawyer, the journalist, the author of works about I.S.Turgenev (f. 740) where the unpublished translations of works of some English poets referring to 1950s, including A.Tennyson, are stored. 
In the book «the European poetry of XIX century», issued in a series «The Library of the world literature» in 1977, among other translations from Tennyson, there was also published M.E.Sokovnin's translation «When the moon on my curtain...», the source of which was LXVII poem from a cycle «In Memoriam» (Tennyson, 1977: 75). By the moment of the publication of this translation M.E.Sokovnin had already died: the talented representative of Russian postmodernism untimely died in 1975. A. Tennyson was one of M.E.Sokovnin's most favourite writers; he had translated two of his poems and tens of pieces of poetry (Kulakov, 1999: 84-87). They remain unpublished up to now in spite of the fact that M.E.Sokovnin «returned» to literature as a prose writer, the author of original poetry in $1990^{\text {th }}$. The main reason for the talented translations not have been published up to now is that the manuscripts of M.E.Sokovnin have not been saved (or perhaps unknown). Texts of translations can be published in case we can decipher film records where he had read them. Now a well-known literary critic, professor A.N.Gorbunov has these materials; he is carrying out preparation of the edition «In Memoriam», which was newly translated by T.Y.Stamova, in a «Literary monuments» series; it is possible to hope, that forty years after M.E.Sokovnin's death some of his translations can at last be issued.

One of the completely unknown published Russian translations of Tennyson's «Home they brought her warrior dead ...» that we can mention is that of a well-known polyglot, Chancellor of the University of Glasgow in 1907-1929 Donald MacAlister named «The Dead Soldier». It entered the «Echoes» collection issued in Glasgow in 1923 (MacAlister, 1923). Among others the collection contained eight Russian translations of the works created in English, Scots, German and Greek, including «Former years» by R.Burns (in the original - «Auld Lang Syne»), «Saying» by W.Scott (in the original - «Lucy's Song»), «Moon» by P.B.Shelley (in the original - «To the Moon»), «Eternal rest» by R.L. Stevenson (in the original - «Requiem»). D.P.Svyatopolk-Mirsky responded with his famous name review «The literary phenomenon» to the publishing of this collection in the emigrant newspaper «Zveno» dated December, 21st, 1925, where he noted metric refinement of translations together with some mistakes in some fine points too difficult for foreigners to understand (Svyatopolk-Mirsky, 1925). The review of Svyatopolk-Mirsky was recently republished in Russia - in 2014 (Mirsky, 2014). A very important publication in Russia devoted to D.MacAlister has been released during the expired period; it was the article by P.Henry called «The Scottish Lomonosov», where the history of the publication of the «Echoes» collection and the review by D.P.Svyatopolk-Mirsky was mentioned (Henry, 1996: 258-259).

Traditionally the years of 1920-1960 are perceived as the time of practically full absence of any new Russian translations of Tennyson (except for three translations by S.Y.Marshak mentioned above). However there were also some other translations, which are nowadays absolutely forgotten. In 1945-1946 L.N.Martynov (poet) published two versions of his translation of «Cradle Song» («The Wind of These Coasts...») in the fifth book of «Omsk Almanac» (Tennyson, 1945) and in the author's poetic collection «Erzin wood» (Tennyson, 1946). Speaking about «a choice of English poetic tradition» made by L.N.Martynov, E.A.Akelkina noted that, alongside with the knowledge of English language, the life itself made him do this. This choice can be regarded as «a remarkable gesture of the beginning of a shy cultural dialogue between former allies that was encouraged by the authority» (Akelkina, 2012: 136). Comparison between two editions of translation with the English original is the subject of a separate article; Here we can only note the advantage of the edition placed in the author's collection - it looks more integrated both in the sense of content and in the sense of the form of a verse. Unfortunately, the collection «Erzin wood» together with the translation of Tennyson placed in it, had a tragic fate: after sharp criticism by V.M.Inber in her article «Escape from reality» in «The Literary newspaper» on December, 7th, 1946, where she made a resolute conclusion - «We are going different ways, Mr. Martynov!» (Inber, 1946), the circulation of the book was annihilated, and now there is only one copy of it in the Russian State Library, which once belonged to the literary critic and bibliophile A.K.Tarasenkov. Nowadays this copy is kept in the Museum of the Book.

The aspiration for dialogue with former allies develops into a forgotten CVI translation by A.B.Svirin of a poem «In Memoriam», printed in 1953 under the name «New Year's bells», into an appeal to eradication of lie, narrow-minded slander and passion to a profit, to a celebration of the truth and of everlasting peace, capable to replace a thousand-year epoch of wars: «Ring out the farewell to troubles, / To Old conflicts that torment the world, / Announce friendship between people, / Kind trust to neighbours» (Tennyson, 1953). The translations by L.N.Martynov and A.B.Svirin alongside with translations by S.Y.Marshak, and the translation «Having started my way on the height of mountains...» published in 1959 by O.B.Rumer who died as far back as in 1954 (Tennyson, 1959), can be in detail considered later as a manifestation of a short-term interest of the Russian literature to A.Tennyson on the background of improvement of relations between Russia and the Great Britain who were the countries-allies during the Second world war.

Tennyson's traditions in the Russian literature become the matter of special studying. In particular, the influence of the image of Godiva by Tennyson (I.A.Bunin's interpretation first of all) on the Russian literature and culture of XX century remains none comprehended. Traditionally only the extract from the poem by O.E.Mandelstam with his reaction on the image of Godiva «With the majestic world I was only childishly connected...» (1931) is quoted. In the final stanza there 
appears the image of an English lady from the far childhood: «Wasn't that because I saw on a children's picture / Lady Godiva with dismissed red mane, / I keep on repeating on the sly: / Lady Godiva, farewell! I do not remember, Godiva ... » (Mandelstam, 2009: 154). However the response of the image of Godiva was much more relevant. In the poem by I.Severyanin «Rocking chair of a dreamer» (1911), addressed to L.D.Ryndina, Godiva is mentioned in one line with much more known Iolanta - the heroine of P.I.Tchaikovsky's opera based on a drama «King René's Daughter» by Danish writer Henrik Hertz (libretto by M.I. Tchaikovsky) and ancient Greek poetess Sappho (Severyanin, 2004: 46). In 1957, having arrived to Russia from the USA, the poet-futurist and artist D.D.Burlyuk visited K.I.Tchukovsky, who asked him to make some notes in the hand-written almanac «Chukokkala». As a result there appeared an illustration to "Godiva» by Tennyson, where the heroine was depicted naked on a horse with her hair fluttering downwind. Sideways D.D.Burlyuk added an eye, possibly belonging to that curious, who dared to peep at Godiva and lost his sight (Chukokkala, 2008: 87). Lady Godiva is also mentioned in the novel «Drops of blood (Navia's charms)» by F.K.Sologub (1905), in the third chapter of the third part of the novel «Herculean pillars» by I.A.Aksenov (1918), in the third chapter of the novel «Jessie and Morgiana» by A.S.Grin (1928), in the story «At the corner of Arbat and Bubulinas street» by G.M.Shergova (1969), in the poems «Incantation in spring» by V.T.Shalamov $(1937,1956)$ and «It's nonsense, it's a trifle ...» by I.V.Chinnov (1986).

Russian poets-translators who actively addressed to English poetry of XIX century and tried to comprehend it were greatly influenced by the poem «In Memoriam» by Tennyson. In this context the lines written by V.A.Merkurieva (who translated in 1930th much of D.G.Byron, P.B.Shelley, etc.) taken from her poem «Tomb of the Unknown Poet» (1933) «Remains are accepted not in crematorium, / Not in Vagankovo, nobody knows whose they are, / Without an inscription in memoriam, / Without wreaths, and without speeches as well» do not seem to be occasional (Merkurieva, 2007: 342). The cycle «In Memoriam» with four other poems was created by N.M.Minsky in 1922 (Minsky, 2005). He is well-known for translations of Tennyson, including «In Memoriam»; as supposed by S.V.Sapozhkov the cycle is devoted to a memory of L.N.Vilkina - his wife and poetesses who died in July, 1920 in Paris (Sapozhkov, 2005: 403). And at last, A.A.Akhmatova has a poem «And you, my friends of the last appeal!..», dated August, 1942; originally it was printed without the title in №2 of the magazine «Banner» in 1945, later in the book of her «Selected Verses» (1946) the title «In Memoriam» did appear (Akhmatova, 1946). We cannot say whether there were any associations with Tennyson. It is impossible to answer unequivocally, especially taking into account that there was a great interest to the literature of the countries-allies in the first post-war years, on the one hand, and the absence of Tennyson's reminiscences and traditions, reference of his name and titles of his works in the compositions of Akhmatova on the other. Besides as revealed by P.Y.Barskova and T.N.Pozdnyakova there is a pencil record in the archive of the translator S.K.Ostrovskaya (who was an agent of special services and is now completely forgotten) about her meeting with Akhmatova on February, 16th, 1945 with the following final words «By the way, does not love Tennyson. We are drinking tea. Vodka» (Barskova \& Pozdnyakova, 2013: 682). It can be found in the Department of manuscripts of the Russian National Library, in the archive of the translator S.K.Ostrovskaya (f. 1448, unit of storage 173, p. 1-3).

\section{Discussion}

The reasons of a special interest of such representatives of democratic direction in the Russian literature as M.L.Mikhailov, D.D.Minaev, A.N.Pleshcheev, who became the pathbreakers in the field of studying Tennyson's creativity in the late 1850 - 1870th, remain debatable. On the background of a complete absence of the published or authentically known translations of Tennyson in those years executed by writers of other ideological views, as well as because of complete discrepancy of civic standpoints of the Russian writers-democrats and of an English conservative-minded poet, this interest can be considered as strange and can be explained by the great responsiveness of writers of democratic camp on novelties of the West-European literature in comparison with all others. Among «The Sixtiers» of XIX century, who were not only interested in creativity of Tennyson, but also loved his works, we can especially mention G.E.Blagosvetov. He was a publisher of a democratically focused «The Russian Word» and «The Affair», who spent a few years (1857-1860) abroad and who combined «burning hatred of Russian backwardness $<\ldots>$ with a worship for the European progress» and who could fall «into cultural delight in the face of a brilliance of a foreign civilization» (Alekseev, 1985: 479). Describing G.E.Blagosvetov in his book of memoirs «Silhouettes of the remote past» P.V.Bykov named A.Tennyson as the first of his favourite authors: «He perfectly understood the spirit of works by Tennyson, Moore, Longfellow, Barbier, and Hugo who were his favourite poets» (Bykov, 1930: 30). It is possible to assume, what it was G.E.Blagosvetov who initiated the process of creating of translations of Tennyson that started appearing in magazines issued by him.

Our home researchers of M.Gorky's creativity have not found anything in common with the works of Tennyson. So 
much interesting were the direct judgments made by an unknown reviewer, who responded to the publication of the story of «Mother» by M.Gorky in his article «Gorky's" Mother"» appeared on pages of «New York Times» on May, 25th, 1907. A True and Pathetic Study of Human Nature - Pelagneya Nilovna and Rizpah». The author of the article, which was translated into Russian by E.I.Bobrova in 1941, saw the common tendencies in M.Gorky's «Mother» and in A.Tennyson's poem «Rizpah»: «Like Tennyson in his poem "Rizpah", M.Gorky in the story "Mother" has touched the very essence of motherhood, something greater than deep, self-denying tenderness, so dear to artists and poets, when the ego of a mother merges with that of a child so that she can exclaim < "Do you think that I care for my soul if my boy be gone to the fire?" A.Tennyson, «Rizpah»>. In the poem by Tennyson the furious parent love pushes mother into an infernal flame near to her son who is doomed to destruction. In the story by Gorky it forces her to share the fate selected by her son that is full of renunciation and danger» (Critical responses, 1941: 396-397). It is hardly possible to speak that A.Tennyson's influenced M.Gorky, it is rather the interest of authors to the same «eternal» theme of a self-denying parent feat that has been shown up in one plane and still differently because of the distinction of epochs, public realities and ideological positions of authors.

In our opinion, it would be useful to attract more diary, memoir and epistolary sources to the analysis that can contradict each other, promoting discussion. So, in the book of memoirs of the poetess and translator «Cities and Meetings» by E.G.Polonskaya one can find some of her old impressions (1910) of a library in a student's hostel in Paris, where the bookcases were filled with books in English and alongside with English-speaking editions (including Tennyson), there were French authors as well: «I went to the second floor and find myself in a spacious room with oak bookcases along the walls and light windows open to a garden. Frames were open, so were the bookcases and I began to examine the books. There were elegant volumes of Dickens, Walter Scott, Keats, and Tennyson. On the other shelf there were Pierre Corneille and Racine, Moliere and Chateaubriand - all in English» (Polonskaya, 2008: 211). However the level of popularity of Tennyson in the continental Europe in the early XX century was absolutely different. S.A.Andreevsky wrote in his sketch «Degeneration of a rhyme» (1900), entered into the book «Literary sketches»: «<...> in England Tennyson - the poet born last century, the laureate of Queen Victoria, poorly spread on the continent - have been living out the remainder of his days» (Andreevsky, 2005: 456).

\section{Conclusions}

As we can see, although there are some significant works published last decades, Russian reception of A.Tennyson still requires fixed and attentive studying. In our article we have only outlined the prospects of the big work, which should be done to recreate the diverse influence of A.Tennyson's texts on creativity of Russian writers, specify their echoes in works of Russian literary critics. When considering the translational reception of Tennyson the most significant and volumetric theme appears to be the analysis of the Russian translations executed in 1970th - the beginning of XXI century and concerning the «Russian theme» in Tennyson's works we can speak about the analysis of Russian acquaintances of the English poet and the facts of his perusal of works of Russian writers. It is necessary to continue the work on revealing and publication of unknown, forgotten and lost Russian translations of works by Tennyson; it is especially possible to encounter such cases in the works of the authors of the Silver age and poets of $1940^{\text {th }}$ - early $1950^{\text {th }}$. It will be of great assistance if we can study the local themes connected with the comprehension of the Russian fate of separate works by Tennyson, and if some works of Russian writers were inspired by some of Tennyson's images. We see perspective in some deeper studying of an Russian original perception of some images from Tennyson's works, in particular, Godiva, Maeldune, Ulysses and dying swan. Once V.A.Kaverin used the motto of the protagonist of the novel «Two captains» (1938-1944) Sanya Grigoriev, who was dreaming about far journeys, taken from the poem «Ulysses» by A.Tennyson «To strive, to seek to find and not to yield». These words with surprising capacity describe a way of seeking and striving and finding, passed by Tennyson himself; they can be also referred to the work of Tennyson's researchers who are on the way of finding a lot of unexpected discoveries.

\section{Acknowledgements}

Research has been carried out within the limits of realization of the project under the grant of the President of Russian Federation MD-5818.2015.6 «Textual criticism and poetics of Russian art translation of XIX - the early XXI century: reception of English poetry of the Victorian Age in synchronism and diachronic». 


\section{References}

Akelkina, E.A. (2012). «Almanac of the Victory ». The Omsk scientific bulletin, 2, 134--137.

Akhmatova, A.A. (1946). The selected verses. Moscow: Truth.

Alexander Block in «Pantheon» (2004). Alexander Block in «Pantheon» and «the World literature»: letters to Z.I.Grzhebin and P.O.Morozov. Introductory article, the publication and comments by A.V.Lavrov and S.S.Grechishkin. In A.V.Lavrov, S.S.Grechishkin. Symbolists neaby. Sketches and publications (pp. 316-322). St.-Petersburg: Skifia; the Publishing house "Talas».

Alexeev, M.P. (1983). Comparative literary criticism. Leningrad: Science.

Alekseev, M.P. (1985). Victor Hugo and his Russian acquaintances. Meetings. Letters. Memoirs. In M.P.Alekseev. Russian culture and the Romane world (pp. 371-508). Leningrad: Science.

Alexeev, M.P. (1991). The English literature. Sketches and researches. Leningrad: Science.

Alexeev, M.P. (1996). Russian meetings of William Morris. In Russia, the West and the East: counter flows. To the 100 anniversary of the date of birth of academician M.P.Alekseev (pp. 3-24). St.-Petersburg: Science.

Andreevsky, S.A. (2005). Degeneration of a rhyme. In S.A.Andreevsky. The book about death. The edition prepared by I.I.Podolskaya (pp. 449-468). Moscow: Science.

Barskova, P.Y. \& Pozdnyakova, T.N. (2013). Comments. In S.K.Ostrovskaya. A diary. Preparation of the text and comments by P.Y.Barskova and T.S.Pozdnyakova (pp. 615-699). Moscow: New literary review.

Buckley, J.H. (1960). Tennyson. The Growth a Poet. Cambridge: Harvard University Press.

Buckley, J.H. (1966). The triumph of time. A study of the Victorian Concepts of Time, History, Progress, and Decadence. Cambridge: Harvard University Press.

Buckley, J.H. (1969). The Victorian temper. A study in literary and culture. Cambridge: Harvard University Press.

Bunin, I.A. (2007). Letters of 1905-1919. Under the general editorship of O.N.Mikhajlov; texts and comments prepared by S.N.Morozov, R.D.Devis, L.G.Golubeva, I.A.Kostomarova. Moscow: Institute of the world literature named after A.M.Gorky of the Russian Academy of sciences.

Bykov, P.V. (1930). Silhouettes of the remote past. Moscow-Leningrad: the Earth and factory.

Chernin, V.K. (2009). Alfred Tennyson and Russia: From history of the international literary ties. Moscow: Flinta; Science.

Chernin, V.K. \& Zhatkin, D.N. (2009a). Poem by Alfred Tennyson «The Lady of Shalott» in Russian translations of the end of XIX century. Philological sciences, 2, 37-46.

Chernin, V.K. \& Zhatkin, D.N. (2009b). Poetic cycle of Alfred Tennyson «In Memoriam» in Russian translations of XIX - early XX century. Bulletin of the Moscow State Regional University. Series Russian philology, 4, 172-176.

Chernin, V.K. \& Zhatkin, D.N. (2009c). Art features of works by Alfred Tennyson in comprehension of D.N.Sadovnikov. Bulletin of the Chita State University, 3, 161-165.

Chernin, V.K. \& Zhatkin, D.N. (2010a). Poem by Alfred Tennyson «Dora» in Russian interpretations of XIX - early XX century. Bulletin of the Yaroslavl State University named after P.G.Demidov. Series The Humanities, 4, 110-114.

Chernin, V.K. \& Zhatkin, D.N. (2010b). Poem by Alfred Tennyson «Ulysses» in translational interpretation by K.D.Balmont. Knowledge. Understanding. Skill, 4, 150-153.

Chernin, V.K. \& Zhatkin, D.N. (2010c). «Russian theme» in literary creativity of Alfred Tennyson in a context of Russian-English public and literary ties of XIX century. News of higher educational institutions. Volga region. Series the Humanities, 2, 58-69.

Chernin, V.K. \& Zhatkin, D.N. (2011). O.N.Chyumina as the translator of a lyrical cycle by Alfred Tennyson about Marianna («Marianna», «Marianna in the South»). Bulletin of the Pyatigorsk State Linguistic University, 1, 176-178.

Chernin, V.K. \& Zhatkin, D.N. (2012). D.L.Mikhalovsky - the translator of fragments of poetic cycle by Alfred Tennyson «In Memoriam». Bulletin of the North-Osetiya State University named after K.L.Khetagurov, 1, 324-328.

Chukokkola (2008). Chukokkola: Hand-written almanac by Korney Tchukovsky. 2 edition., revised. Moscow: Russian way.

Critical responses (1941). Critical responses of the American press of 1907 about the story «Mother». Introductory article and translation by E.I.Bobrova. In Maxim Gorky. Materials andresearches. V. 3. Under editorship of S.D.Balukhaty and V.A.Desnitsky (pp. 391403). Moscow-Leningrad: Publishing house of the Academy of sciences of the USSR.

D.B. [Baikov, D.V.] (1895). Bibliographic note. In A. Tennyson. Magdalena (Mood). Poem. Translation by A.M.Fedorov (pp. 1-2). Moscow: Print. D.V.Baikov's.

D.S.M. [Svyatopolk-Mirsky, D.P.]. (1925). A literary phenomenon. Zveno, 151 (21 th of December), 2.

Elistratova, A.A. (1960). Heritage of English romanticism and the present. Moscow: Publishing house of the Academy of sciences of the USSR.

Etkind, E.G. (1963). Poetry and translation. Leningrad: Soviet writer.

Fedorov, A.V. (1983). Art of translation and life of the literature. Sketches. Leningrad: Soviet writer.

Gachechiladze, G.R. (1972). Art translation and literary interrelations. Moscow: Soviet writer.

Girivenko, A.N. (1993). Alfred Tennyson in Russia: about history of perception. In Materials of history of Russian culture of XIX-XX centuries (pp. 21-32). Bryansk: Publishing house of the Bryansk State Pedagogical Institute named after I.G.Petrovsky.

Girivenko, A.N. \& Nedachina, A.R. (1995). English literature in the Russian criticism. Bibliographic index: In 2 books. Book 2. XIX century: In 2 parts. Part 2. Moscow: Institute of the scientific information on social studies.

Hair, D.S. (1981). Domestic and Heroic in Tennyson's Poetry. Toronto: University of Toronto Press. 
Henderson, P. (1978). Tennyson: Poet and prophet. London: Routledge and Kegan Paul.

Henry, P. (1996). The Scottish Lomonosov..? In Russia, the West and the East: counter flows. To the 100 anniversary of the date of birth of academician M.P.Alekseev (pp. 256-262). St.-Petersburg: Science.

Inber, V.M. (1946). Escape from reality. The literary newspaper, $7^{\text {th }}$ of December, 4.

Kulakov, V.G. (1999). Alfred Tennyson in translations by Michael Sokovnin. In V.G.Kulakov. Poetry as the fact. Articles about verses (pp. 84-87). Moscow: New literary review.

Levin, Y.D. (1985). Russian translators of XIX century and development of art translation. Leningrad: Science.

Lunts, L.N. (2004). I. The posthumous literature about Block. II. New poets. T.A.Kukushkina's publication. In The Year-book of the Handwritten department of the Pushkin House dd. 2000 (pp. 383-412). St.-Petersburg: Dmitry Bulanin.

Lunts, L.N. (2007). The Literary heritage. The foreword, comments, drawing up and preparation of texts by A.L.Evstigneeva. Moscow: Scientific world.

MacAlister, D. (1923). Echoes. Glasgow: Maclehose Jackson and Co.

Mandelstam, O.E. (2009). «With the majestic world I was only childishly connected ...». In O.E.Mandelstam. Complete collection of works and letters: In 3 v. V. 1. Poems (pp. 153-154). Moscow: Progress-galaxy.

Merkurieva, V.A. (2007). A tomb of the unknown poet. In V.A.Merkurieva. Vainness. Collection of poems (pp. 342-343). Moscow: Publishers Vodoley.

Mikhalskaya, N.P. (1995). An image of Russia in English fiction of IX - XIX centuries. Moscow: Publishing house of the Moscow Pedagogical State University.

Milsand (1851). English poetry after Byron: Alfred Tennyson. Library for reading, 10, 71-95.

Minsky, N.M. (2005). In Memoriam. In Russian symbolists: N.Minsky, A.Dobrolyubov. Introductory article, preparation of the text, drawing up and notes by A.A.Kobrinsky and S.V.Sapozhkov (pp. 255-257). St.-Petersburg: Academic project.

Mirsky D. (2014). Literature phenomenon. In D.Mirsky. About the literature and art. Articles and reviews 1922-1937. Drawing up, preparation of texts and comments by O.A.Korostelev and M.V.Efimov; introductory article by G. Smith (pp. 134-135). Moscow: New literary review.

Pavshok, L.M. (2008). Creativity of Alfred Tennyson: aspects of poetics. The author's abstract from the Cand.Phil.Sci dissertation. Moscow: The Moscow State University named after M.V.Lomonosov.

Polonskaya, E.G. (2008). Cities and meetings. The book of memoirs. Introductory article, drawing up, preparation of the text, comments, an epilogue and selection of illustrations by B.Y.Frezinsky. Moscow: New literary review.

[Porgues, E.D.]. (1847). Alfred Tennyson and modern English poetry. [From «Revue de Deux mondes»]. The literary newspaper, 28 (July, 10th), 442-443; 29 (July, 17th), 456-457.

Reisov, B.G. (1966). Correlative-comparative studying of literatures. In Questions of methodology of literary criticism (pp. 171-196). Moscow-Leningrad: Science.

Ricks, Ch. (1972). Tennyson. London: Macmillan.

Ryabinin, A.N. (1918). After a thunder-storm. Verses. Petrograd: the Murom printing.

Sapozhkov, C.V. (2005). Notes [to «N.M.Minsky» section]. In Russian symbolists: N.Minsky, A.Dobrolyubov. Introductory article, preparation of the text, drawing up and notes by A.A.Kobrinsky and S.V.Sapozhkov (pp. 318-474). St.-Petersburg: Academic project.

Severyanin, I. (2004). Rocking chair of a dreamer. In I.Severyanin. A Thunder burning cup. Pineapples in champagne. A nightingale. Classical roses. The edition prepared by V.N.Terekhina, N.I.Shubnikova-Guseva (pp. 46-47). Moscow: Science.

Sokolova, N.I. (1999). Shakespeare's traditions in the poem «The Princess» by Tennyson. The genre theory on a threshold of millennia. The collection of theses and materials of IX annual conference of the Russian association of teachers of the English literature (pp. 119-121). Moscow: Publishing house of the Moscow Pedagogical State University.

Tennyson, A. (1859). Godiva. Translation by M.L.Mikhailov. The Contemporary, 9, 5-8.

Tennyson, A. (1893). Ulysses. Translation by N.M.Minsky. In Way Road. The scientific-literary collection in favour of the Society of a relief aid to requiring immigrants (pp. 117-119). St.-Petersburg: B.M.Volf's lithography.

Tennyson, A. (1897). Memories of a friend. Translation by N.M.Minsky. The world divine, 4, 235.

Tennyson, A. (1945). A wind of delight and cool. Translation by L.N.Martynov. In The Omsk almanac. Book 5 (p. 81). Omsk: Omgiz.

Tennyson, A. (1946). Cradle Song («Wind of these coasts ...»). Translation by L.N.Martynov. In L.N.Martynov. Erzin wood (pp. 125126). Omsk: Omgiz.

Tennyson, A. (1953). New Year bells. Translation by A.B.Svirin. Youth of the world, 12, 4.

Tennyson, A. (1959). «Having started my way on the height of mountains...». Translation by O.B.Rumer. In Rumer O.B. The selected translations. Composed by A.A.Anikst (p. 120). Moscow: Soviet writer.

Tennyson, A. (1977). Lotofagi. Translation by G.M.Kruzhkov; «When the moon on my curtain...». Translation by M.E.Sokovnin; Godiva. Translation by I.A.Bunin; To ***, after perusal of «Live and letters». Translation by G.M.Kruzhkov; At the sea-side. Translation by S.Y.Marshak; "Why, what is the reason of these strange tears?..». Translation by V.V.Rogov; Tithonus. Translation by A.Y.Sergeev. In The European poetry of XIX century. Introductory article by S.A.Nebolsin; Drawing up by V.Bogachev, I.Bochkareva, S.Velikovsky, etc. (pp. 74-82). Moscow: Fiction.

Tennyson and modern direction (1847). Tennyson and modern direction of poetry in England. Finnish bulletin, 6, 26-32.

Tennyson, modern English poet (1853). Tennyson, modern English poet. Pantheon, 5, 9-97.

The provincial bibliographer [Bakhtin, H.H.] (1892). Foreign writers in the Russian literature: Tennyson. Bibliographic a note, 11, 811- 
812.

Thomson, A.W. (1986). The poetry of Tennyson. London: Routledge and Kegan Paul.

Toper, P.M. (2001). Translation in the system of comparative literary criticism. Moscow: Heritage.

Turner, P. (1976). Tennyson. London: Routledge and Kegan Paul.

Volodarskaya, L.I. (2001). Bibliography of Russian translations (first edition). In A.Tennison. Idylls of the King. Translation by V.V.Lunin (pp. 450-453). Moscow: Grant.

Waddington, P. (1987). Tennyson and Russia. Lincoln: Tennyson Research Centre.

Zhatkin, D.N. \& Chernin, V.K. (2014). Publications of Russian translations and transpositions of works by A.Tennyson. Bibliographic inquiry. In Alfred Tennyson in Russian translations of XIX - early XX century. Drawing up and preparation of texts by of D.N.Zhatkin and V.K.Chernin (p. 700-707). Moscow: Flinta; Science. 